\title{
On-board diagnostic system for vehicle state assessment
}

\begin{abstract}
The paper presents a concept of an on-board diagnostic system for the assessment of vehicle state in critical situation. A vehicle state assessment is done by an analysis of given signals recorded by on-board devices. A vehicle state is described by providing its position, velocities, accelerations, rotations and also powetrain data related to engine and other vehicle parts in operation. The first prototype of this device has already been developed. It registers signals taken from inertial modules such as linear and angular accelerometers (gyroscopes) and geographical coordinates from GPS. The data from GPS together with the data from inertial modules are written into a text file and can then be visualized by geo-information software. Accelerometers will be used for detection of engine malfunctions using vibroacoustic signals analysis and for vehicle position identification and the support of GPS.
\end{abstract}

Key words: on-board diagnostic systems, GPS, vibroacoustic signal processing

\section{System diagnostyki pokładowej do oceny stanu pojazdu}

\begin{abstract}
Praca prezentuje system diagnostyki pokładowej stużacy do oceny stanu pojazdu w celu wykrywania sytuacji krytycznych. Ocena stanu pojazdu jest dokonywana poprzez analizę wybranych sygnałów rejestrowanych przez urządzenia diagnostyki pokładowej. Stan pojazdu jest opisany przez podanie jego położenia, prędkości, przyspieszeń, obrotów oraz danych na temat działania silnika i innych elementów pojazdu. Prototyp takiego urządzenia został zbudowany i rejestruje sygnaty otrzymywane za pomoca inercjalnych modułów, takich jak liniowe i katowe akcelerometry oraz wspótrzędne geograficzne za pomoca urządzenia GPS. Dane z GPS razem z danymi z modulów inercyjnych sa zapisywane do pliku tekstowego i moga być następnie wizualizowane przez geo-informacyjne instrumenty programowe. Akcelerometry będa stosowane do detekcji uszkodzeń silnika spalinowego na bazie analizy sygnałów wibroakustycznych oraz do identyfikacji położenia pojazdu i wspomagania wskazań GPS.
\end{abstract}

Słowa kluczowe: systemy diagnostyki pokładowej, GPS, przetwarzanie sygnałów wibroakustycznych

\section{Introduction}

An important element of each modern vehicle fleet management system is the use of highly specialized on-board devices for recording and detection of critical situations. A critical situation is any risky incident in which a moving vehicle can fail, be damaged in a collision, which may subsequently result in passenger death or injury, damage of goods and environment pollution. A risky incident can be predicted from data related to exceeding of the limit velocity or acceleration, improper velocity in relation to the road conditions (e.g. bends in railroad tracks), brake and engine damage and other malfunctions of the vehicle. A risky incident can be influenced by a collision of two vehicles, collision of vehicle with an obstacle or a derailment, engine dysfunctions, excess speed, inclination angle etc.

The results presented in the paper can have application both in railroad and vehicle industry. In the case of vehicles the proposed methods are generally known but also in this area there are some problems interesting for investigation e.g. the application of accelerometers and gyroscopes for the support of GPS readouts. In railroads the proposed solution is new, especially in Poland.

Railroad is becoming a more and more important, vital and popular means of transportation and will have to fulfill

\section{Wstęp}

Ważne dla każdego nowoczesnego systemu zarządzania flotą pojazdów jest zastosowanie wysoko wyspecjalizowanych urządzeń pokładowych do zapisywania i wykrywania sytuacji krytycznych. Sytuacja krytyczna to dowolny ryzykowny incydent, podczas którego poruszający się pojazd może być uszkodzony w wyniku awarii lub kolizji, co może prowadzić do śmierci lub zranienia pasażerów, uszkodzenia przewożonych towarów lub zanieczyszczenia środowiska. Ryzykowny wypadek może być przewidziany na podstawie danych o przekroczeniu dozwolonej prędkości lub przyspieszenia, niewłaściwej prędkości w stosunku do warunków (np. na zakrętach), uszkodzeniach silnika i hamulców oraz o innych awariach pojazdu. Mogą one być wywołane przez zderzenie dwóch pojazdów, zderzenie pojazdu z przeszkodą, wypadnięcie z trasy ruchu, awarie silnika, przekroczenie prędkości lub kąta nachylenia itp.

Wyniki przedstawione $\mathrm{w}$ pracy mają zastosowanie zarówno dla ruchu kolejowego, jak i samochodowego. Dla samochodów omówione metody są już znane, ale również na tym polu zastosowań istnieje nadal wiele interesujących problemów do badań, np. zastosowanie akcelerometrów i żyroskopów do wspomagania odczytów GPS. Dla składów kolejowych proponowane rozwiązanie jest nowe, szczególnie dla ruchu kolejowego w Polsce. 
new requirements and will need new management to improve safety, comfort and reliability.

The on-board diagnostic system presented in the paper is designed for an on-line monitoring and management in railroad and vehicle traffic. The main aim of this system is detection of critical situations in railroad traffic and performance of a full assessment of the risk of accident needed for a full knowledge of a current vehicle state [12, 17, 20, 21, 23].

A vehicle state is acquired by determining of its position, direction, accelerations, rotations, inclination, engine state etc. The corresponding data should contain information on the engine malfunctions, leaks, vibrations, geographical position, railroad conditions etc.

Accident control and management of traffic need special sophisticated methods for detection, prediction and recognition $[11,13,20,23,24,25]$. In order to do this some special signal processing methods and approaches based on artificial intelligence should be applied (see e.g. $[8,11,24,13])$. So far, they have mostly been used for vehicle motion control on highways and for modeling, prediction and prevention of railroad accidents.

A practical application of the GPS systems in accidents control and management of traffic should be realized together with the application of GIS systems [12, 13, 17, 19, 25]. This can give us the representation of a vehicle route on the map. In general, the combination of GIS and GPS data allows finding a vehicle position in the case of an accident and also gives additional information such as weather and rail condition. The significant task for GPS/GIS system is automatic vehicle location in accident management and fleet monitoring.

The GPS in railroad is mostly applied in the measurement of location and geometry of the railroad track. There are also many practical trials with application of GPS systems for accident management and fleet monitoring, e.g. [9, 20, 21].

It is worth underlining that artificial intelligence methods are often applied in determination of vehicle state and prediction of accidents. Such automatic incident detection systems used e.g. the Bayesian decision systems and artificial neuranetworks $[11,13,23]$.

\section{The on-board diagnostic system for vehicle state assessment}

The general diagram of the proposed system is presented in Fig. 1. As one can find from Fig. 1 the main sensors considered and applied are:

- accelerometers - trajectory reconstruction and vibroacoustic diagnosis,

- GPS - position detection, trajectory reconstruction and velocity determination,

- gyroscopes - trajectory, tilts and rollovers reconstruction.

The analysis of signals registered by ORD devices is a very complex process $[7,10,14,15,16]$. It contains both high technology of signal recording and sophisticated algorithm and software for signal processing. One can
Transport kolejowy staje się ostatnio ważnym i coraz bardziej popularnym środkiem transportu. Będzie więc musiał w najbliższej przyszłości spełnić nowe wymagania i będzie potrzebował nowego zarządzania, aby zwiększyć bezpieczeństwo, komfort jazdy i niezawodność.

Opisany w pracy system diagnostyki pokładowej jest zaprojektowany do monitorowania i zarządzania "on-line" ruchem kolejowym i samochodowym. Głównym celem systemu jest wykrywanie krytycznych sytuacji w transporcie kolejowym, a do oceny ryzyka wypadków potrzebna jest wiedza o bieżącym stanie pojazdu [12, 17, 20, 21, 23].

Stan pojazdu jest dany przez określenie jego pozycji, kierunku ruchu, przyspieszeń, obrotów, nachyleń, stanu silnika itp. Odpowiednie dane powinny więc zawierać informacje o uszkodzeniach silnika, wyciekach, wibracjach, pozycji geograficznej, warunkach drogowych itp.

Do zarządzania ruchem i przewidywania wypadków potrzeba wyspecjalizowanych metod wykrywania, przewidywania i rozpoznawania $[11,13,20,23,24,25]$. Do tego celu można zastosować metody przetwarzania sygnałów oraz niektóre wybrane metody bazujące na sztucznej inteligencji (np. [8, 11, 24, 13]). Zostały one już zastosowane do kontroli ruchu na autostradach oraz do modelowania, przewidywania i zapobiegania wypadkom drogowym.

Praktyczne zastosowanie systemów GPS do zarządzania ruchem i przewidywania wypadków powinno być realizowane razem z użyciem systemów GIS [12, 13, 17, 19, 25]. Daje to możliwość zaprezentowania trasy pojazdu na mapie. Ogólnie łączenie danych GIS i GPS pozwala znaleźć pozycję pojazdu, gdy doszło do wypadku oraz dostarczyć dodatkowej informacji na temat np. warunków pogodowych, stanu torowiska itp. Znaczącym zadaniem wypełnianym przez systemy GPS/GIS jest automatyczna lokalizacja pojazdu w zarządzaniu wypadkami oraz monitorowaniu floty pojazdów.

W kolejnictwie dotychczas GPS jest stosowany przede wszystkim do pomiarów położenia i geometrii szyn. Prowadzi się również dużo prób z zastosowaniem GPS do zarządzania wypadkami oraz monitorowania floty pojazdów $[9,20,21]$.

Warto podkreślić, że do określenia stanu pojazdu oraz przewidywania wypadków często stosowane są metody sztucznej inteligencji. Wybrane systemy automatycznego wykrywania wypadków wykorzystują np. bayesowskie systemy decyzyjne albo sztuczne sieci neuronowe [11, 13, 23].

\section{System diagnostyki pokładowej do oceny stanu pojazdu}

Ogólny schemat zaproponowanego systemu jest pokazany na rys. 1 . $\mathrm{Z}$ analizy rys. 1 wynika, że głównymi rozważanymi i stosowanymi czujnikami są:

- akcelerometry - rekonstrukcja trajektorii oraz diagnostyka bazująca na sygnałach wibroakustycznych,

- GPS - wykrywanie pozycji, rekonstrukcja trajektorii oraz określania prędkości pojazdu,

- żyroskopy - rekonstrukcja trajektorii, przechyłów i obrotów. 
find here many interesting research problems and application of specialist signal processing methods (e.g. nonlinear methods) and artificial intelligence methods.

In the system presented in the paper, the main analysis mainly concerns signal processing methods applied into vibroacoustic signals. In this area, together with classic spectral methods that base on Fourier analysis, other methods were applied:

- nonlinear analysis (basing on deterministic chaos theory and on Takensa and Mañé theorem)

- short-time signal analysis (with application of pattern recognition techniques like clustering).

The initial aims in this area were misfire detection and detection of an engine state. Experiments were carried out on a Diesel locomotive engine and on one cylinder test engine and showed the dominant Lyapounov exponents were significantly higher for the case of misfire in comparison with the case with all cylinders working. A misfire was simulated by the disconnection of an injector in one cylinder of the engine. Two kinds of vibroacoustic signals were compared: an improper signal (misfire simulated by disconnection of one cylinder) and a proper signal (all cylinders operative) $[1,2,4]$.

Other types of investigations were done based on the comparison of vibroacoustic signals taken from an engine before and after the repair of a Diesel locomotive. Periodic inspection repair included service of sub-assemblies and assemblies, partial disassembling and change of damaged or worn-out elements. The research object was a Diesel locomotive engine in a diagnostic station. The sensors were mounted on the engine body in the spots near the engine crankshaft bearing [6].

In this area short time methods showed significant differences between cluster centers in parameter space for signals before and after the repair. In turn, nonlinear methods showed that dominant Lyapunov exponents had higher values for signals after the repair and they distinguished between normal and 'worn out' engine state $[3,5]$.

The simplest diagnostic method was the use of single statistical parameters such as the mean, the moments, the median etc. Unfortunately the research with this method did not show significant results. The single parameter analysis was insufficient to perform a complete classification. The problem was solved using the SVM method. The experiments were done using SVM Classifier [18] with the use of C-SVM and nu-SVM algorithms. A comparison of SVM algorithms was based on the classification accuracy and at the current stage of the research both linear and radial kernels showed very big efficiency (even 100\% in some cases). Generally, the SVM method has shown good results of classification of the vibroacoustic signals taken
Accelerometers and gyroscopes MEMS for rajectory reconstruction

Velocity and other parameters from extra OBD devices

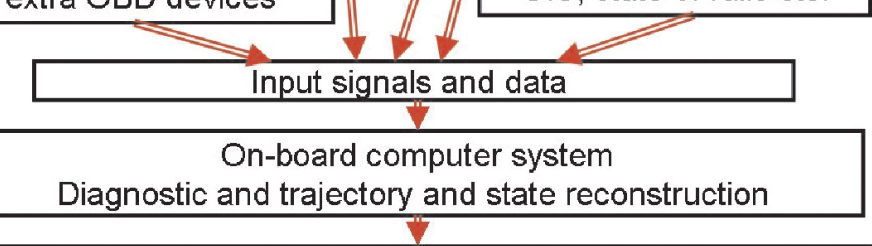

Determination of rail vehicle state, position and trajectory Detection and identification of critical situations

Fig. 1. General diagram of the proposed in the paper on-board diagnostic system for vehicle state assessment

Rys. 1. Ogólny schemat zaproponowanego systemu diagnostyki pokładowej do określania stanu pojazdu

Analiza sygnałów rejestrowanych przez urządzenie ORD jest skomplikowanym procesem $[7,10,14,15,16]$. Zawiera on zarówno zaawansowane technologicznie pozyskiwanie sygnału, jak i skomplikowane algorytmy i oprogramowanie do przetwarzania sygnałów. W tym zakresie można znaleźć wiele interesujących problemów badawczych i możliwość zastosowania specjalistycznych metod przetwarzania sygnałów (np. metod nieliniowych) oraz metod bazujących na sztucznej inteligencji.

W systemie zaproponowanym w niniejszej pracy główne metody analizy to metody przetwarzania sygnałów zastosowane do sygnału wibroakustycznego. W tym zakresie, obok klasycznych metod spektralnych bazujących na analizie Fouriera, zastosowano wybrane metody:

- analiza nieliniowa (bazująca na teorii chaosu deterministycznego i twierdzeniu Takensa i Mañé),

- analiza krótkoczasowa (z zastosowaniem technik rozpoznawania obrazów, takich jak grupowanie danych).

Początkowym celem badań była detekcja wypadania zapłonu oraz wykrywanie stanu silnika spalinowego. Eksperymenty przeprowadzone na silniku Diesla lokomotywy spalinowej oraz na 1-cylindrowym silniku badawczym pokazały, że maksymalne wykładniki Lapunowa miały znacząco wyższe wartości dla przypadku wypadania zapłonu niż dla przypadku, gdy wszystkie cylindry pracowały właściwie. Wypadanie zapłonu było symulowane przez odłączanie zasilania jednego cylindra. Dwa podstawowe rodzaje sygnałów wibroakustycznych były porównywane: sygnał niewłaściwy (wypadanie zapłonu symulowane odłączeniem cylindra) $\mathrm{i}$ sygnał właściwy (wszystkie cylindry pracują) $[1,2,4]$.

Inny rodzaj badań był przeprowadzony na bazie porównania sygnałów wibroakustycznych zarejestrowanych z silnika Diesla lokomotywy spalinowej przed i po remoncie. Okresowy remont polegał na pełnym serwisie części układów oraz na wymianie elementów uszkodzonych lub zużytych. Obiektem badawczym był silnik Diesla lokomo- 
from an engine before and after the repair $[6,8,9,22]$. The results show the usefulness of the SVM method in the classification of diesel engine states. The only problem for these investigations is the recording of a greater amount of training data.

Another interesting problem in on-board recording system construction is the assessment of vehicle trajectory and its state using GPS technology together with inertial sensors. Generally, in practice one can find many systems applied for on-line detection of a vehicle state. They are called ORD (On-Board Recording Devices) systems, OBD (On-Board Diagnostic) systems, EDR (Event Data Recorder) systems or sometimes simply black box systems. They are used especially in cars and planes but so far there has been no such solution in railroad systems. Many of the considered solutions and concepts are not new but still they constitute here a very complex engineering task.

First experiments have shown that a trajectory reconstruction depends on the accuracy of position determination and precision of digital maps and satellite images.

In practice, each commercial GPS receiver uses communication protocol NMEA (National Marine Electronics Association). Usually, not all NMEA commands are implemented. Some NMEA announcements give the direction of velocity in degrees in a system of reference connected to the ground and a velocity module in $\mathrm{km} / \mathrm{h}$ or knots. In NMEA binary mode there is access to additional information depending on the manufacturer and type of sensor, for example velocity vector components (along axes: longitudinal, latitudinal and vertical). The velocity is not usually determined from the calculation of the path over time but from the Doppler Effect.

First tests were conducted with a Telit GM862-GPS module with an evaluation kit EVK2 that has a built-in GPS receiver, GSM modem with GPRS technology and a Python script interpreter. It comprises only one 10-bit analogue input and the processing power of the unit is not very impressive, however is sufficient for simple tracking purposes, receiving, processing and answering text messages, e-mails and data transmitted via GPRS.

Then, some simple applets were written to tests suitability for vehicle tracking and remote diagnostics. For instance, gathered information is sent in a text message, in a response to an SMS containing valid password and one of the available commands. The SMS solution is not an optimum one for each application, so subsequently other means of available communication such as SMTP/ POP3, TCP/IP, UDP protocols are to be evaluated and used.

The prototype of the designed recorder received a name of MEREX. MEREX uses a GPS sensor Garmin GPS16. Using of Garmin GPS 16 enables producing more accurate position coordinates using differential corrections in the RTCM SC-104 standard with DGPS (Differential Global Positioning System) technology, which is an enhancement to GPS that uses a network of ground-based reference sta- tywy spalinowej na stacji diagnostycznej. Czujniki były mocowane na korpusie silnika w miejscach odpowiadających łożyskom wału korbowego [6].

$\mathrm{W}$ tych badaniach interesujące wyniki dały metody krótkoczasowe. Pokazały one znaczące różnice pomiędzy środkami grup w zakresie parametrów odpowiadających sygnałom przed i po naprawie. $Z$ kolei metody nieliniowe pokazały, że maksymalne wykładniki Lapunowa miały wyższe wartości dla sygnału po naprawie i potrafiły rozróżnić stan silnika zużytego od pracującego normalnie $[3,5]$.

Najprostszą metodą diagnostyczną było zastosowanie pojedynczych parametrów statystycznych, takich jak średnia, momenty, mediana itp. Niestety, badania w tym zakresie nie przyniosły znaczących rezultatów. Analiza sygnałów za pomocą pojedynczych parametrów nie pozwoliła na przeprowadzanie pełnej klasyfikacji. Problem został rozwiązany dzięki zastosowaniu metody SVM. Odpowiednie eksperymenty i badania przeprowadzono z użyciem SVM Classifier [18], który wykorzystywał algorytmy C-SVM oraz nu-SVM. Porównanie różnych wersji algorytmów SVM oparto na dokładności klasyfikacji (ang. classification accuracy) i na aktualnym etapie badań zarówno liniowe, jak i radialne jądra dały bardzo wysoką sprawność (nawet $100 \%$ w niektórych przypadkach). Metoda SVM wykazała wysoką jakość klasyfikacji sygnałów zarejestrowanych na silniku przed i po naprawie $[6,8,9,22]$. Ostateczne rezultaty pokazały użyteczność metody SVM do klasyfikacji stanów silnika spalinowego. Jedynym problemem zacytowanych badań jest ciągle mała liczba danych treningowych.

Innym interesującym i znaczącym zagadnieniem podczas konstrukcji i uruchamiania pokładowych systemów rejestrujących jest określanie trajektorii pojazdu i jego stanu na podstawie wskazań GPS oraz czujników bezwładnościowych. W praktyce można znaleźć wiele typów rozwiązań stosowanych do rejestrowania "on-line" stanu pojazdu. Sa to tzw. systemy ORD (On-Board Recording Devices), OBD (On-Board Diagnostic), EDR (Event Data Recorder) lub po porostu systemy czarnych skrzynek. Używane są one przede wszystkim w samolotach i samochodach, ale do tej pory brak jest powszechnych rozwiązań tego typu na kolei. Tak więc wiele $\mathrm{z}$ rozważanych $\mathrm{w}$ tym artykule problemów nie jest całkiem nowych, ale cały czas stanowią one skomplikowane $\mathrm{i}$ istotne zadanie inżynierskie.

Pierwsze eksperymenty pokazały, że rekonstrukcja trajektorii zależy mocno od dokładności określenia pozycji oraz precyzji map cyfrowych i zdjęć satelitarnych.

W praktyce każdy komercyjny odbiornik GPS używa protokołu komunikacyjnego NMEA. Zwykle nie wszystkie komendy NMEA są wykorzystywane. Niektóre komunikaty NMEA podają informację o kierunku prędkości w stopniach, w układzie współrzędnym związanym z terenem oraz moduł prędkości $\mathrm{w} \mathrm{km} / \mathrm{h}$ lub węzłach. W binarnym trybie NMEA można znaleźć dostęp do dodatkowych informacji - zależnie od producenta oraz od typu czujnika, na przykład składowe wektora prędkości (wzdłuż osi równoleżnikowej, południkowej i pionowej). Warto podkreślić, że prędkość nie jest zwykle określana na podstawie obliczania przebytej drogi w czasie, ale na podstawie efektu Dopplera. 
tions and RTK (Real Time Kinematics) technique based on the use of carrier phase measurements.

MEREX recorder has a color LCD display, foil keyboard, independent battery supply, SD/MMC memory card (16 GB), Atmel AVR32UC3A0512 processor. It gives a measurement of three accelerations in three perpendicular directions.

MEREX recorder allows a measurement, data acquisition and transmission to a PC computer by a build-in USB port. Additionally the standard GPS receiver can be connected to MEREX. The messages in the NMEA standard are recorded synchronously with the data from the inertia sensors.
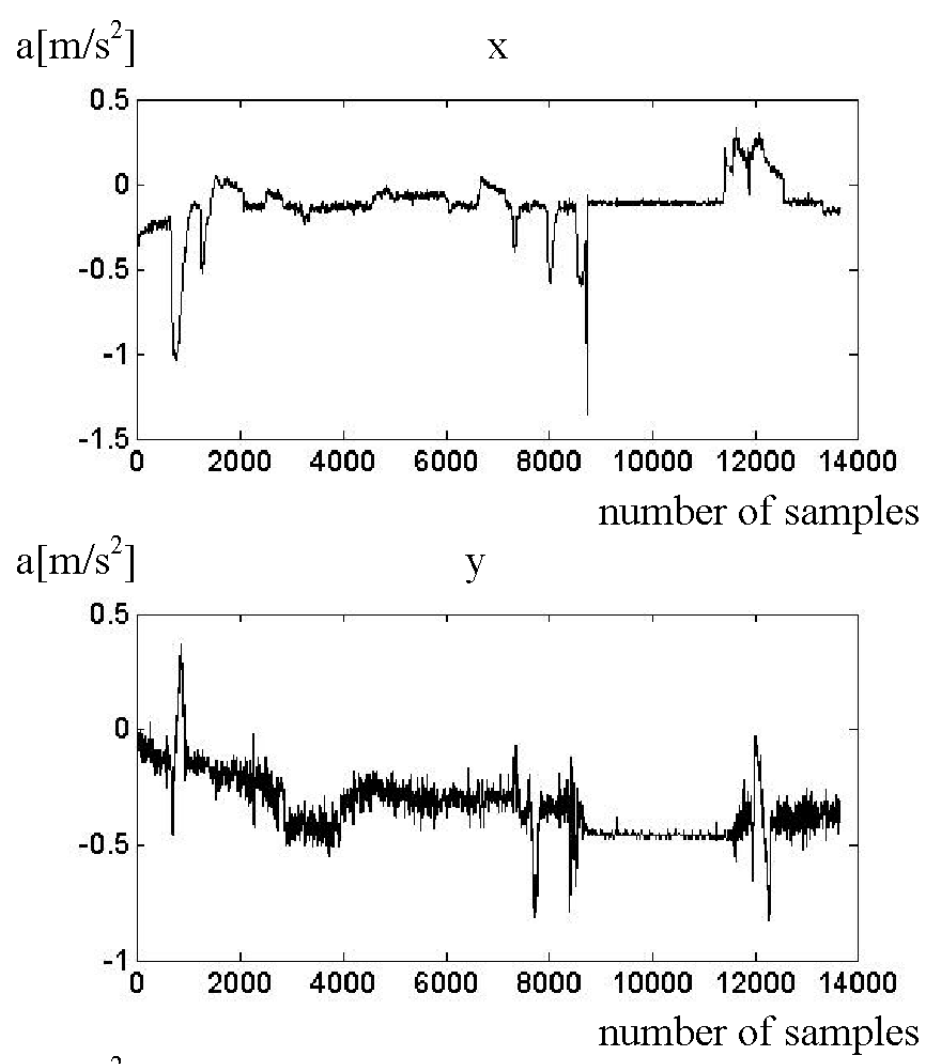

$\mathrm{a}\left[\mathrm{m} / \mathrm{s}^{2}\right]$

Z

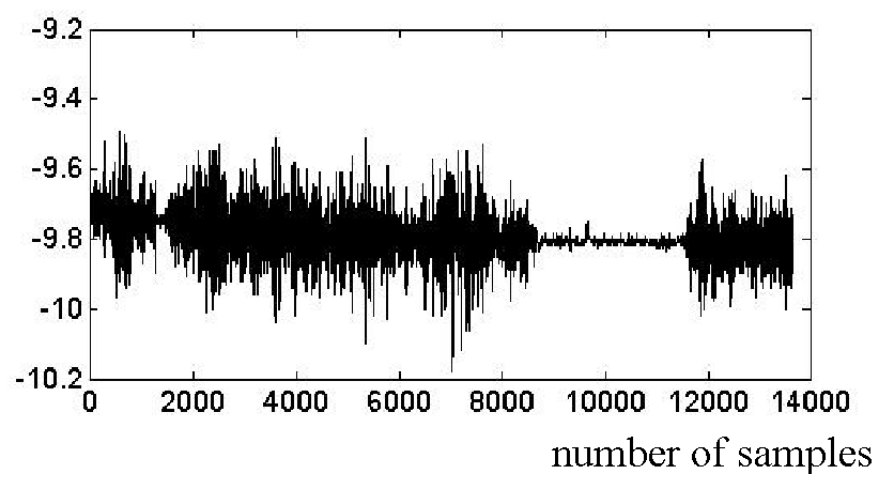

Fig. 2. Exemplary plots of acceleration in $\mathrm{x}, \mathrm{y}$ and $\mathrm{z}$ directions. A recorder was placed in a passenger car of a fast train. A recorder was turned on during train moving and continued till stop and start from a station

Rys. 2. Przyktadowe wykresy przyspieszenia w kierunkach $x$, y oraz $z$. Rejestrator byt umieszczony $w$ wagonie osobowym pociagu pospiesznego.

Rejestrator właczono podczas ruchu pociagu, pomiar byt kontynuowany podczas postoju na stacji i ponownego ruszenia
Pierwsze testy przeprowadzone zostały z modułem Telit GM862-GPS (wraz z zestawem EVK2), który ma wbudowany odbiornik GPS, modem GSM w technologii GPRS oraz interpreter skryptów Python. Ma on jedynie 10-bitowe wejście analogowe, a moc przetwarzania jednostki obliczeniowej nie jest najwyższa, jednak wystarcza do prostego śledzenia, do otrzymywania, przetwarzania i odpowiadania na wiadomości tekstowe, emaile oraz dane transmitowane techniką GPRS.

Następnie napisane zostały proste aplety w celu sprawdzenia przydatności do testowania śledzenia pojazdu i zdalnej diagnostyki. Na przykład, zgromadzona informacja była wysyłana w postaci wiadomości tekstowej w odpowiedzi na SMS zawierający ważne hasło i jedną $\mathrm{z}$ dostępnych komend. Rozwiązanie $\mathrm{z}$ użyciem SMS nie jest optymalne $\mathrm{w}$ wielu zastosowaniach, toteż inne dostępne środki komunikacji, takie jak protokoły SMTP/POP3, TCP/IP, UDP muszą być sprawdzone i zastosowane.

Prototyp zaprojektowanego rejestratora nazwano MEREX. Rejestrator MEREX wykorzystuje czujnik GPS typu Garmin GPS16. Użycie urządzenia Garmin GPS16 daje możliwość wyznaczenia bardziej dokładnych współrzędnych pozycji przy użyciu korekcji różnicowej w standardzie RTCM SC-104 w technologii DGPS (Differential Global Positioning System), która jest rozszerzeniem klasycznego GPS przez użycie naziemnej sieci stacji odniesienia oraz techniki RTK (Real Time Kinematic), która bazuje na użyciu pomiaru przeniesienia fazy.

Rejestrator MEREX ma kolorowy wyświetlacz LCD, foliową klawiaturę, niezależne zasilanie bateryjne, kartę pamięci SD/MMC oraz procesor Atmel AVR32UC3A0512. Daje on pomiar przyspieszenia w trzech prostopadłych kierunkach przestrzennych.

Rejestrator MEREX pozwala na pomiar, zapamiętanie danych oraz ich transmisję do komputera PC przez wbudowany port USB. Do rejestratora można dodatkowo podłączyć standardowy odbiornik GPS. Komunikaty w standardzie NMEA są zapisywane synchronicznie razem z danymi z czujników bezwładnościowych.

MEREX używa karty MMC/SD i jest przystosowany do rejestracji sygnałów mierzonych przez moduł inercyjny (liniowe i kątowe przyspieszenia) oraz pozycji określanej przez podłączony czujnik GPS. Wiadomości generowane przez GPS opisujące bieżąca pozycję obiektu, jego prędkość i kierunek ruchu razem $\mathrm{z}$ danymi z modułu bezwładnościowego są zapisywane jako plik tekstowy.

Równocześnie z rejestracją trasy z użyciem GPS określano dodatkowe informacje opisujące dokładność określania pozycji (osłabienia precyzji VDOP, HDOP, PDOP oraz liczba satelitów).

Warto podkreślić, że pozyskiwane w eksperymentach sygnały żyroskopowe byłyby bezwartościowe 
MEREX uses a MMC/SD card and ultimately registers signals measured by an inertial module (linear acceleration, angular acceleration) and position determined using the connected GPS sensor. The messages generated by the GPS describing the current position of an object, its velocity and movement direction together with the measurement data from the inertial module, are recorded as a text file

Registering of routes using GPS also gives some additional information describing position accuracy (dilution of precision VDOP, HDOP, PDOP and number of satellites).

The semiconductor gyroscope signals acquired in the experiments are worthless in reconstruction of the movement trajectory of vehicles without an application of special dedicated algorithms for the compensation of drift and temperature susceptibility.

A significant variability of integrated position readings is found of a motionless system of three gyroscopes ADIS16255. Depending on the temperature, after several hundred seconds the readings reach the value of a full turn $360^{\circ}$.

\section{Results}

The MEREX recorder can detect all excess accelerations and show the admissible values of accelerations on a railroad vehicle body in Poland $\left(1.0 \mathrm{~m} / \mathrm{s}^{2}\right.$ till $5.0 \mathrm{~m} / \mathrm{s}^{2}$ depending on vehicle type and measurement direction). The testing of the acceleration and position measurements of the rail vehicles was done. The tests included the traffic of a typical passenger train, shunting of railroad cars and the ride of a locomotive through crossovers (e.g. see Fig. 2).

The data from the MEREX recorder can be visualized and presented as a route on a map (see Fig. 3). The prepared scripts and software allow a conversion of text communications in NMEA standard from the GPS to a form which allows an easy visualization with the use of commonly applied formats and instruments such as Google Earth using $\mathrm{KML} / \mathrm{KMZ}$ format, one of the most popular format of geo-information data.

\section{Conclusions}

The introductory investigations on the application of various ORD devices (accelerometers, MEMS gyroscopes, GPS) have shown a large complexity of sensors, circuit fitting and adjustments. The problem of finding a vehicle trajectory turns out to be quite complex, especially in the presence of exterior disturbances and a more complex type of motion.

In the area of on-board recording there are many important current and future problems to solve. One is a combination of the GPS and inertial modules data to produce relevant information. Cooperation of GPS and GIS is also

dla rekonstrukcji trajektorii bez zastosowania specjalnych dedykowanych algorytmów do kompensacji dryftu i wrażliwości na zmiany temperatury. Jest to powodowane wielką zmiennością zintegrowanych odczytów pozycji nawet nieruchomego systemu trzech żyroskopów ADIS16255. Zależnie od temperatury po czasie kilkunastu sekund odczyty osiągają wartość pełnego obrotu, czyli $360^{\circ}$.

\section{Wybrane rezultaty}

Rejestrator MEREX jest w stanie rejestrować wszystkie przekroczenia wartości przyspieszenia i odtworzyć pełny zakres dopuszczalnych przyspieszeń dla pojazdu torowego $\mathrm{W}$ Polsce (od 1,0 m/s $/ \mathrm{s}^{2}$ do $5,0 \mathrm{~m} / \mathrm{s}^{2}$ zależnie od rodzaju pojazdu i kierunku pomiaru). Przeprowadzono testy pomiarów przyspieszenia i pozycji dla pojazdów szynowych. Testy obejmowały ruch typowego pociągu pasażerskiego, przetaczanie wagonów oraz jazdę lokomotywy przez rozjazdy (np. rys. 2).

Dane z rejestratora MEREX można wizualizować i pokazać jako trasę na mapie (rys. 3). Przygotowane skrypty i oprogramowanie pozwalają na przetworzenie tekstowych komunikatów w standardzie NMEA z GPS do postaci, która pozwala na łatwą wizualizację z użyciem powszechnie stosowanych formatów i instrumentów, takich jak Google Earth w formacie KML/KMZ, który jest jednym z bardziej popularnych formatów danych geo-informacyjnych.

\section{Wnioski}

Wstępne badania nad zastosowaniem różnych urządzeń ORD (akcelerometry, żyroskopy MEMS, GPS) pokazały wielką złożoność elektroniki (czujniki, dopasowanie i korekcja obwodów). Problem znajdowania trajektorii pojazdu okazał się skomplikowany, szczególnie ze względu na obecność zewnętrznych zakłóceń i bardziej złożonych rodzajów ruchu. 
a problem and it can be solved using refined artificial intelligence methods. Full integration of signals from the inertia sensors, such as gyroscopes and accelerometers with the GPS system is all the time the core of the developed system. For sensor fusion algorithms there is a need to apply powerful microprocessors.

Generally, the presented results indicate the usefulness of the proposed methods for detecting critical situations and assessment of a vehicle state in railroad transportation.

The tests and the investigations in this matter are still continuing. The future aim is a full study and implementation of an on-board system for monitoring, management and detecting critical situations in railroad traffic.

Paper reviewed/Artykut recenzowany
W zakresie badań nad pokładowymi rejestratorami jest ciągle wiele ważnych bieżących i przyszłych problemów do rozwiązania. Jednym $z$ nich jest połączenie danych GPS oraz danych pochodzących z czujników bezwładnościowych. Również współpraca GPS z GIS może stanowić duży problem, którego rozwiązanie wymaga wyrafinowanych metod sztucznej inteligencji. Pełna integracja sygnałów z czujników bezwładnościowych, takich jak żyroskopy i akcelerometry ze wskazaniami GPS cały czas stanowi klucz do systemów rekonstrukcji trajektorii pojazdu. Algorytmy dokonujące fuzji danych wymagają stosowania mikroprocesorów dużej mocy.

Zaprezentowane wyniki wskazują na użyteczność zaproponowanej metody dla detekcji sytuacji krytycznych $\mathrm{i}$ oceny stanu pojazdu $\mathrm{w}$ transporcie, a $\mathrm{w}$ tym również $\mathrm{w}$ transporcie kolejowym.

Testy i badania w tym zakresie są ciągle kontynuowane. Celem przyszłym jest pełne studium i implementacja pokładowego systemu dla monitorowania, zarządzania i wykrywania krytycznych sytuacji w transporcie kolejowym.

\section{Nomenclature/Skróty i oznaczenia}

DGPS Differential Global Positioning System/technika GPS zwiększonej doktadności

DOP Dilution of precision/ostabienie precyzji

EDR Event Data Recorder/rejestrator danych o wypadkach

GIS Geographical Information Systems/geograficzny system informacyjny

GPRS General Packet Radio Service/technologia stosowana $w$ sieciach komórkowych do pakietowego przesyłania danych

GPS Global Positioning System/globalny system wyznaczania pozycji

HDOP Horizontal Dilution of Precision/poziome ostabienie precyzji

KML/KMZ Keyhole Markup Language/Keyhole Markup Language/język wykorzystywany $w$ opisie danych geograficznych

LCD Liquid Crystal Display/wyświetlacz ciekłokrystaliczny

MEMS Micro Electro-Mechanical Systems/mikrosystemy elektromechaniczne

NMEA National Marine Electronics Association/standard komunikacyjny używany w GPS opublikowany przez National Marine Electronics Association z USA

OBD On-Board Diagnostic Device/pokładowe urzadzenie diagnostyczne
ORD On-Board Recording Devices/pokładowe urzadzenie rejestrujace

PC Personal Computer/komputer osobisty

PDOP Position Dilution of Precision/pozycyjne ostabienie precyzji

RTCM Radio Technical Commision for Maritime/standard transmisji poprawek różnicowych w systemie DGPS

RTK Real Time Kinematic/technologia pomiarów GPS

SD/MMC Security Digital/Multimedia Card/standard karty pamięci

SMS Short Message Service/usługa przesyłania krótkich wiadomości tekstowych

SMTP/POP3 Simple Mail Transfer Protocol/Post Office Protocol version 3/protokót komunikacyjny używany przy przesytaniu emaili

SVM Support Vector Machine/maszyna wektorów wspierających

TCP/IP Transmission Control Protocol/Internet Protocol/model protokołów komunikacyjnych stosowany w Internecie

UDP User Datagram Protocol/protokót internetowy

USB Universal Serial Bus/uniwersalna magistrala szeregowa

VDOP Vertical Dilution of Precision/pionowe ostabienie precyzji

\section{Acknowledgments}

Praca była finansowana z pracy badawczej No N509 $04732 / 3308$

\section{Podziękowania}

Praca była finansowana z pracy badawczej No N509 $04732 / 3308$ 


\section{Bibliography/Literatura}

[1] Abarbanel H.D.I.: Analysis of observed chaotic data, Springer 1996.

[2] Boguś P., Merkisz J., Grzeszczyk R., Mazurek S.: Nonlinear analysis of combustion engine vibroacoustic signals for misfire detection. SAE Technical Paper Series 2003-01-0354.

[3] Boguś P., Lewandowska K.: Short-time signal analysis using pattern recognition methods. Artificial Intelligence and Soft Computing ICAISC 2004, LNAI Lecture Notes in Artificial Intelligence, vol. 3070, Springer, pp. 550-555, 2004.

[4] Boguś P., Merkisz J.: Misfire Detection of locomotive diesel engine by nonlinear analysis. Mechanical Systems and Signal Processing vol. 19, pp. 881-899, 2005.

[5] Boguś P., Merkisz J.: Short time analysis of combustion engine vibroacoustic signals with using pattern recognition techniques. SAE Technical Paper Series 2005-01-2529.

[6] Boguś P., Sienicki A., Wojciechowska E., Merkisz J.: The Comparison of vibroacoustic signals taken from an engine before and after repair. Combustion Engines, vol. 2007-SC3 - PTNSS, pp. 300-306, 2007.

[7] Boguś P., Merkisz J., Mazurek S., Grzeszczyk R.: Detection of critical situations in rail transport using ORD motion parameters. Proceedings of the 10th International Conference on Application of Advanced Technologies in Transportation, Athens, Greece, May 28th - 30st, pp. 1-10, 2008.

[8] Boguś P., Merkisz J., Mazurek S.: The prospect of artificial intelligence methods in identification and prevention of critical railroad accidents. Computational Intelligence: Methods and Applications, EXIT, Warsaw, pp. 445-453, 2008.

[9] Boguś P., Merkisz J., Idzior M., Grzeszczyk R.: Detecting critical situations in railroad traffic through on-board diagnsotic system. Proceedings of The 14th World Multi-Conference on Systemics, Cybernetics and Informatics. June 29th - July 2nd, 2010 - Orlando, Florida, USA. Volume II, pp.56-61, 2010.

[10] Boguś P., Grzeszczyk R.: Uncovering and detection of dail dehicle state using GPS and other on-board recorders. Pojazdy Szynowe, No 2, pp. 13-23, 2010 (in Polish).

[11] Gao X.Z., Ovaska S.J.: Soft computing methods in motor fault diagnosis. Applied Soft Computing, vol. 1, pp. 73-81, 2001.

[12] Hegyi F., Mookerjee A.K.: GIS and GPS based asset management for Road and Railroad Transportation Systems in India. 6th Annual International Conference, Map India 2003, 28-30 January, 2003, New Delhi, India, 2003.

Piotr Boguś, DSc., DEng. - Head of Department of Physics and Biophysics of Medical University of Gdańsk, docent at Rail Vehicle Institute TABOR in Poznan.

Dr hab. inż. Piotr Boguś - kierownik Katedry $i$ Zakładu Fizyki i Biofizyki Gdańskiego Uniwersytetu Medycznego, docent w Instytucie Pojazdów Szynowych TABOR w Poznaniu.

e-mail:piotr.bogus@amg.gda.pl

Rafał Grzeszczyk, DEng. - director of Automex sp. z o.o., Gdansk.

Dr inż. Rafat Grzeszczyk - dyrektor Automex sp. z o.o., Gdańsk.

e-mail: rafal.grzeszczyk@automex.pl
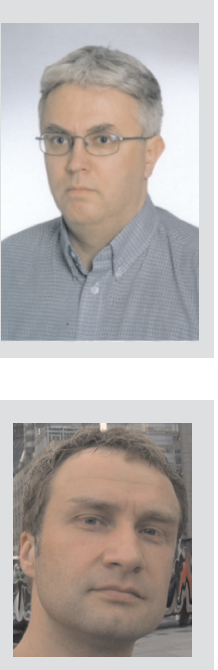
Modeling, vol. 22, pp. 259-268, 1995.
Prof. Jerzy Merkisz, DSc., DEng. - Professor in the Faculty of Working Machines and Transportation at Poznan University of Technology.

Prof. Jerzy Merkisz - profesor na Wydziale Maszyn Roboczych i Transportu Politechniki Poznańskiej.

e-mail: jerzy.merkisz@put.poznan.pl

[13] Kumar P., Reddy D., Singh V.: Intelligent transport system using GIS. 6th Annual International Conference, Map India 2003, 28-30 January, New Delhi, India, 2003.

[14] Mening P., Coverdill C.: Transportation recorders on commercial vehicles. International Symposium on Transportation Recorders, Arlington, Virgina, 1999.

[15] Merkisz J., Mazurek S.: On-board recording systems of cars. Wydawnictwa Komunikacji i Łączności, Warszawa 2002.

[16] Merkisz J., Boguś P., Wrona A.: Using signals of registered linear and angular acceleration to reconstruct the trajectory of vehicles' movement. 9th EAEC International Congress "European Automotive Industry Driving Global Changes", 16-18 June 2003-Paris, Paper No C203, 2003.

[17] Mintsis G., Basbas G., Papaioannou P., Taxiltaris C., Tziavos I. N.: Application of GPS technology in the land transportation system. European Journal of Operational Research, vol. 152, pp. 399-409, 2004.

[18] Pirooznia M., Deng Y.: SVM Classifier - a comprehensive java interface for support vector machine classification of microarray data. BMC Bioinformatics vol. 7, Suppl 4:S25, 2006.

[19] Theiss A., Yen D.C., Ku C.Y.: Global positioning systems: an analysis of applications, current development and future implementations, Computer Standards and Interfaces vol. 27, pp. 89-100, 2005.

[20] Thill J.C.: Geographic information systems for transportation in perspective. Transportation Researches, Part C, vol. 8, pp. 3-13, 2000.

[21] Tyrell D.C.: Rail passenger equipment accidents and the evaluation of crashworthiness strategies. Proceeding of the Institution of Mechanical Engineering, Part F, Journal of Rail and Rapid Transit vol. 216, pp 2002, pp. 131-147, 2002.

[22] L. Wang (ed.): Support vector machines: Theory and Applications, Springer-Verlag 2005.

[23] Wootton J.R., Garcia-Ortiz A.: Intelligent transportation systems: a global perspective. Mathematical and Computer

[24] Yuan F., Cheu R.L.: Incident detection using support vector machines. Transportation Reserches, Part C, vol. 11, pp. 309328, 2003.

[25] Zito R., D'Este G., Taylor M.A.P.: Global Positioning System in the time domain: How useful a tool for intelligent vehiclehighway systems? Transportation Researches C vol. 3, pp. 193-209, 1995.

Adam Wrona, DEng. - financial director of Automex Sp o. o. in Gdansk.

Dr inż. Adam Wrona-zastępca dyrektora ds. technicznych Automex sp. z o. o., Gdańsk. e-mail:adam.wrona@automex.pl 